[3] Artificial Cloud-Glow. For producing the intense diffraction colours of the cloud-glow it is necessary to procure a cloud consisting of small particles all about the same magnitude. This is best attained if the air before entering the globe is first led through hot water. If the conditions are favourable the colours are sufficiently intense as to permit of their being received on a white screen one metre distant. 'The colours change rapidly in a regular gradation of order, each colour appearing first at the centre of the field, and moving ouiwards.

Several additional phenomena are to be observed with this apparatus ; and its inventor has devised an ingenious proof of the once-disputed point that the particles of mist are spherules, not vesicles. This he does by showing that certain diffraction phenomena which depend on the size of the particles remain unchanged during a sudden change of external pressure, which, if the particles were bubbles or vesicles, would at oncc cause them to expand.

\section{ILLUMINATION OF MICROSCOPES AND BALANCES}

IN measurements and weighings where high scientific 1 accuracy is needed it is sometimes necessary to use artificial means of illumination, and it is found that when reflected light cannot be conveniently introduced, the heat from ordinary lamps causes variations of the temperature of the room, \&c., which slightly affect the accuracy of the results to bc obtained. By using, however, an incandescent electric lamp fitted inside a glass vesscl of water, the light may be even brought near to the microscope or balance without any appreciable interference with temperature. The glass vessel is provided with a pierced cover or shade, and a little stream of water of a uniform temperature may be kept flowing through the vessel.

By means of a "chromozone" battery, supplied by Mr. O. March, it has been found, at the Standards Office, that a light may be maintained at an insignilicant cost for fifty hours without, of course, any attention. During a recent comparison made by $\mathrm{Mr}$. Chaney of two standard kilogram weights it became neccssary to use the lamp, but the action of the balance was not interfered with by the proximity of the lamp, the probable error of the result being only $\pm 0.005 \mathrm{mgr}$.

\section{NOTES}

IN an ovcrflowing Convocation at Oxfurd, on Tucsday, the battle of viviection was fought out a third time. The victory of souxd sense over false scntiment has again heen won; and on this occasion the vote is unmistakable. In spite of the most vigorous exertions of the opponents of physiology, the decree to endow the Physiological Laboratory-as the other scientific departments in the University are endowed-has been carried by the large majority of one hundred and sixty-eight. The Dean of Christchurch opened the debate in a moderate speech recommending the grant. He pointed out that the vate was for teaching purposes, and in no way concerned viviscction, for Prof. Burdon Sanderson had given the must complete assurances that he would not use painful experiments on living animals for the purposes of traching. Canon Liddon opposed the clecree on the ground that the Council should have introdnced further safeguards against the indiscriminate use of vivisection. He admitted that vivisection was justified in certain casce, and spoke of it as a painful necessity. The Bishop of Oxford denicd the moral right of man to inflict pain in order to advance knowledge, and declared vivisection to be degrading to the sensibility and humanity of thic operator. The vote was supported by Prof. Diccy and Sir W. Anson, ans unintentionally damaged by Dr. Acland. The last speakers were much inter- rupted by a clamour which prevented their remarks being hcard. The announcement of the result-placels, $4 \mathrm{I} 2$; nonplacets, 244-was received with great enthusiasm, both in the arena and in the undergraduates' gallery. It is to be hoped that this decisive vote will put an end to the warfare waged against the teaching of physiology in Oxford.

Georogises throughout the world will be interested to learn that Dr. Franz Ritter von Hauer, who for so many years has so admirably guided the progress of the Geological Survey of Austria, has resigned his post as Director of that institution, and has been appointed Intendant of the Impcrial-Royal Natural History Museum, Vicnna. He carries with him intes his new sphere of labour the hearty good wishes of a large circle of friends and well-wishers, who hope that the official dutics he must now perform will in no way diminish the service he has rendered to science so long and so usefully.

Ir has been proposcd that, for the present session, in place of the formal receptions which have hitherto heen held, the rooms of the Royal Society should be kept open on certain nights in order that Fcllows and their friends may meet together for conversation and for the examination of such objects of interest as may be collected for the occasion. The first of these mectings will take place on Thursday, March 19, fron 7.30 p.m. Any one desirous of showing on that evening any experiments, apparatus, or specimens illustrating any inquiry in which he may be engaged, should communicate with the $\Lambda$ ssistant Secretary, in order that appropriate arrangements may be made.

THE death is announced of the eminent Russian geologist, George Helmersen, at the age of eighty-two. IIe studied at Dorpat under Engelhardt, whom he accompanied on his scientific journey along the course of the Lower Volga and the Ural. IIe subsequently took part in IIofmann's and Humboldt's explorations of the Ural region. Having conpleted his studies, especially in mineralogy, he spent some years, by direction of the Russian $\mathrm{G}$ svernment, in geological travels through Germany, Austria, and Switzerland. In 1835 he joinerl the body of mining cngineers, and was appointed Jirector of Studies at the Mining Institute in St. Petersburg. During leisure periods he carried out a series of important geological journeys over the Kirghiz Steppe, through Norway and Sweden, the coal districts of Poland and Silesia, the mining districts of Lakes Onega and Peipus, and the bituminous coal region in the governments of Kherson and Kiev. He also thoroughly explored the gold mines at Beresovsk, and traced the course which has been fol. lowed in making the Ural Railway. The results of his indefatigahls industry have been publisbed in numerous memoirs of the Russian Academy of Sciences and other works.

We have heard with regret of the untimely dcath of the eminent Russian naturalist, Mr. N. Scvertsoff, which occurred on the evening of January II, when driving across the Don, in the Government of Voronej, his horses and vehicle breaking through the ice. The coachman manager to extricate Mr. Severtsoff, but the thermometer stood at $-10^{\circ}$ Réaumur, and, before he could be taken to a neighbouring village, he was frozen to dcath. It is a singular coincidence that Prof. Fedchenko, anothcr of the greatest of Central Asian naturalists, who, like Mr. Severtsoff, had so often risked his life in the pursuit of science in Turkestan, was alses frozen to death in Europe. Mr. Severtsoff so early as 1867 explored the Thian Shan as far as the sources of the Narin. IIis work on the vertical and horizontal distribution of Turkestan animals was written in Russian, and he has since published uriginal researches on the birds of the Pamir. Certain portions of his remarks on 'Turkestan mammals and birds have been translated, and it is chiclly to him that we are indebted for what information we have in English respecting the mammals, hirds, and reptiles of 